\title{
Effect of competence health cultivation on the prevention and control of inadvertent perioperative hypothermia
}

\author{
(D) Ran Wang ${ }^{1}$ \\ (iD) Fu-Min Ping ${ }^{\mathbf{1}}$ \\ (iD) Yue-Mei Liu² \\ (iD)ing-Lan $\mathrm{He}^{2}$ \\ iD Shu-Fang Du \\ (iD) Pei-Zhao Shi \\ (iD) Song Chen ${ }^{2}$ \\ (iD) i-Yue Shi ${ }^{3}$
}

1. Department of Operative, Affiliated Hospital of Hebei University of Engineering, Handan 056002, Hebei, China. 2. Department of Orthopedics, 3Department of Pain, Affiliated Hospital of Hebei University of Engineering, Handan 056002, Hebei, China. 3. Department of Pain, Affiliated Hospital of Hebei University of Engineering, Handan 056002, Hebei, China.

http://dx.doi.org/10.1590/1806-9282.66.7.924

\section{SUMMARY}

OBJECTIVE: To explore the feasibility of health competence cultivation on the prevention and control of Inadvertent Perioperative Hypothermia (IPH).

METHODS: Patients with expected spinal surgery were divided into group A and group B by the random number method. Group B followed routine IPH management, and health training measures for performance and ability were implemented in Group A. The scores of the health competence questionnaire, the temperature at different times, IPH complications, and hospitalization for the two groups were observed and compared.

RESULTS: The main evaluation indexes, such as the health competence questionnaire score, temperature fluctuations, and IPH complications, during the perioperative period in group $A$ were significantly better than those in group $B(p<0.05)$. The indexes of anesthesia, total hospital expenses, and health service satisfaction in group $A$ were also significantly better than those in group $B$, which shows the advantages of cultivating health capabilities in both doctors and patients.

CONCLUSION: Through health competence cultivation and feasible health management measures, the medical staff can improve the quality of IPH prevention and management.

KEYWORDS: Perioperative period. Hypothermia. Health management.

\section{INTRODUCTION}

Inadvertent Perioperative Hypothermia (IPH) refers to the core body temperature of non-hypothermic patients below $36^{\circ} \mathrm{C}$ during the perioperative period, which is the main cause of serious complications such as perioperative cardiac accidents, increased bleeding, and post-operative infection'.

DATE OF SUBMISSION: 14-Oct-2019

DATE OF ACCEPTANCE: 19-Jan-2020

CORRESPONDING AUTHOR: ji-Yue Shi

Department of Pain, Affiliated Hospital of Hebei University of Engineering

Congtai Road, n.81, Congtai District, Handan, Hebei, China - 056002

E-mail: jiyue_shi2@foxmail.com 
With the deepening of basic and clinical research, the whole process of low-body-temperature prevention and control technologies, such as pre-heat treatment during the induction period of anesthesia, body-surface hot-air insulation, whole-course heated-liquid infusion, and preoperative high-energy diet, as well as the whole process of nursing management technology are becoming more and more mature ${ }^{2,3}$. The direct risk factors of IPH are visceral tissue exposure, large temperature difference between the inside and outside of the body, and a high liquid-evaporation heat transfer coefficient. The adoption of preventive advanced technology and control equipment, to a certain extent, reduces the rate of occurrence of $\mathrm{IPH}^{3}$. For example, preheating management during the anesthesia induction period under whole-course core-body-temperature monitoring, mechanical respiratory circuit heating, whole-course intravenous infusion fluid heating or temperature-controlled pressure infusion, temperature management of non-operative parts, especially limbs in hot-air bags, hot-liquid irrigation in the operation field, etc. At the same time, we should improve doctors' standards of diagnosis and treatment and the level of medical humanistic services, enhancing the ability of doctors and patients to cooperate in the prevention and control of medical risks ${ }^{4}$. The expansion of IPH prevention and control technology and the promotion of medical humanities services can significantly improve the quality of perioperative management of patients undergoing surgery. Meta-literature data shows that $30 \%$ to $60 \%$ of patients had body temperature lower than $36^{\circ} \mathrm{C}$ one hour after anesthesia recovery, $72 \%$ of the patients with unexpected ICU monitoring and treatment after the operation had delayed anesthesia recovery or cardio-cerebrovascular complications caused by hypothermia after the operation, and $45 \%$ of the patients with delayed discharge from the daily operation were due to postoperative hypothermia ${ }^{5}$ IPH is a challenge for both doctors and patients, so can we: improve the health competence level of both doctors and patients through targeted health education or professional ability cultivation; guide patients to actively, scientifically, and reasonably refer to perioperative health management; strengthen doctors' professional responsibility and risk prevention and control ability; and further reduce or mitigate the health damage caused by IPH?

\section{METHODS}

IPH defect analysis

Literature studies ${ }^{6}$ believe that the existing measures lack of patient's active participation in the guidance and assessment management of doctor's active prevention and control behavior makes IPH prevention and control management face bottlenecks; the cultivation and application of health competence in perioperative patients' health management is a new concept, whether patients can effectively adapt to the risks of surgical treatment, and whether they can cooperate with doctors to effectively improve remains unknown. Raising the level of IPH prevention and control should be an effective way to break through the bottleneck.

\section{Doctor-patient health risk perception:}

In view of IPH as a health risk factor, patient risk perception, risk prevention and control skills, cooperation efficiency, and expected evaluation are the key to active prevention and control. The assessment of overall health risk factors and targeted health education are important parts of risk reduction and the improvement of patients' health competence level ${ }^{7}$. Anesthesiologists in the department of anesthesia and specialized wards lack traditional medical education, practical clinical diagnosis and treatment processes and norms, and cultivation and assessment management of health education ability.

\section{Education on prevention and evaluation of $\mathrm{IPH}$}

Based on the recognition of health competence theory and practical defects, the path to prevention and control and evaluation criteria based on IPH health competence were formulated after discussion (Table 1). Doctors' and patient's level of information on IPH's physical-mental-social health damages was clarified, and the corresponding countermeasures were formulated; the equipment, technology and management processes already applied were optimized, and the following aspects were strengthened: identification of the risk factors for IPH as a whole; improvement of the perioperative physiological health competence skill from spiritual-social health guidance; highlighting the overall health management service and evaluation of the benefits of IPH prevention and control from the perspective of health economy; clarification of the effect of group IPH prevention and control, highlighting effective cooperation between doctors 
and patients, and emphasizing the coordination and detail management ability of head nurses in the operating room.

\section{IPH prevention and control scheme based on} health competence

The management process, core measures and indicators of doctor-patient health competence education and IPH prevention and control were formulated with the approval of the Academic Ethics Committee of the hospital (see table 2), and a questionnaire was designed based on the score of health competence for IPH prevention and control. The key points were as follows: doctors and patients discuss the standard, and the preventive and control management measures until a consensus is reached; timely coordination of medical and nursing teams could enable targeted preventive and control management measures. (3) Individualized selection and standardized implementation of overall health assessment and whole-process temperature monitoring management; (4) Harmonized and unified recognition of patients' health comfort; medical and nursing occupational comfort; and patients' participation in the management of their safety standards; (5) Knowledge and management of safety indicators of expected health maintenance quality; operating room head nurses combine a management role and ability assessment throughout the process.

\section{Health competence training and question- naire survey}

Medical staff health competence training on IPH prevention and control adopted the random lottery method to divide the head doctors or nurses, anesthesiologists, and operating room nurses in the four orthopedic wards of our hospital into two groups, i.e., A and B. Group A was trained by health competence guidance and evaluation experts on this subject; Group B was trained by the head nurses of the operating room for routine IPH prevention and control management, before and after training and research implementation. The questionnaire for health competence in IPH prevention and control was used to evaluate the health competence scores of head doctors and nurses in the two groups. Two groups of patients were responsible for the training of ward and operating room nurses, respectively, in patients hospitalized, 48 hours before surgery, 72 hours after surgery, and 4 hours before discharge for health competence on IPH prevention and control using the questionnaire and targeted training.

TABLE 1. IPH PREVENTION AND CONTROL EDUCATION AND EVALUATION CRITERIA BASED ON COMPETENCE HEALTH

\begin{tabular}{|c|c|c|c|c|}
\hline $\begin{array}{l}\text { Competence } \\
\text { Health }\end{array}$ & Risk Elements & $\begin{array}{l}\text { Patient Education and } \\
\text { Evaluation }\end{array}$ & $\begin{array}{l}\text { Medical Education and } \\
\text { Evaluation }\end{array}$ & Expected Indicators \\
\hline \multirow[t]{3}{*}{$\begin{array}{l}\text { Physiological } \\
\text { Competence } \\
\text { Health }\end{array}$} & $\begin{array}{l}\text { Diagnosis and treatment of } \\
\text { physiological abnormalities }\end{array}$ & $\begin{array}{l}\text { Preoperative evaluation of } \\
\text { physiological function }\end{array}$ & $\begin{array}{l}\text { Omnidirectional Risk Assess- } \\
\text { ment Ability }\end{array}$ & $\begin{array}{l}\text { Individual physiological } \\
\text { health indicators can be } \\
\text { based on }\end{array}$ \\
\hline & Central hypothermia & $\begin{array}{l}\text { Whole-course temperature } \\
\text { monitoring and management }\end{array}$ & $\begin{array}{l}\text { Regulations and Professional } \\
\text { Insight }\end{array}$ & $\begin{array}{l}\text { Scientific and Reasonable } \\
\text { Equipment Technical Data }\end{array}$ \\
\hline & Physiological function injury & $\begin{array}{l}\text { Visceral Compensation and } \\
\text { Prevention and Control }\end{array}$ & $\begin{array}{l}\text { Risk Awareness and Recogni- } \\
\text { tion Preventive Ability }\end{array}$ & $\begin{array}{l}\text { Precise Regulation and Time- } \\
\text { ly Emergency Prevention and } \\
\text { Control }\end{array}$ \\
\hline \multirow{3}{*}{$\begin{array}{l}\text { Spirit } \\
\text { Competence } \\
\text { Health }\end{array}$} & Health cognitive impairment & $\begin{array}{l}\text { Medical risk and coping } \\
\text { Education }\end{array}$ & $\begin{array}{l}\text { Health Humanities and Med- } \\
\text { ical Effectiveness Evaluation }\end{array}$ & $\begin{array}{l}\text { Health Cognition and IPH } \\
\text { Knowledge Sharing }\end{array}$ \\
\hline & $\begin{array}{l}\text { Psychological adaptation } \\
\text { disorder }\end{array}$ & $\begin{array}{l}\text { Early Warning Guidance } \\
\text { and Assistant Intervention } \\
\text { Management }\end{array}$ & $\begin{array}{l}\text { Occupational Behavior Hab- } \\
\text { its and Care }\end{array}$ & $\begin{array}{l}\text { Understanding Care and Joint } \\
\text { Response under Expected } \\
\text { Goals }\end{array}$ \\
\hline & Abnormal moral behavior & $\begin{array}{l}\text { Risk Communication and } \\
\text { Moral Behavior Guidance }\end{array}$ & $\begin{array}{l}\text { Professional Ethics and } \\
\text { Patient Participation in Man- } \\
\text { agement }\end{array}$ & $\begin{array}{l}\text { Behavior Regulation and } \\
\text { Sharing under Security } \\
\text { Expectation }\end{array}$ \\
\hline \multirow{3}{*}{$\begin{array}{l}\text { Social } \\
\text { Competence } \\
\text { Health }\end{array}$} & Role Recognition Adaptation & $\begin{array}{l}\text { Patient Role Adaptation and } \\
\text { Family Care }\end{array}$ & $\begin{array}{l}\text { Professional Role and Profes- } \\
\text { sional Behavior Standards }\end{array}$ & $\begin{array}{l}\text { Role Orientation and Behav- } \\
\text { ior Appropriateness }\end{array}$ \\
\hline & Medical Expenditure Burden & $\begin{array}{l}\text { Family Economic Burden and } \\
\text { Medicare Model }\end{array}$ & $\begin{array}{l}\text { Medical Benefit Welfare and } \\
\text { Patient Health }\end{array}$ & $\begin{array}{l}\text { Optimal Medical Benefit } \\
\text { Based on Quality and Safety }\end{array}$ \\
\hline & $\begin{array}{l}\text { Communication, coordina- } \\
\text { tion and understanding }\end{array}$ & $\begin{array}{l}\text { Active and Passive Com- } \\
\text { munication and Cultural } \\
\text { Understanding Ability }\end{array}$ & $\begin{array}{l}\text { Health Education and Risk } \\
\text { Sharing Awareness }\end{array}$ & $\begin{array}{l}\text { Risk Consensus Awareness } \\
\text { and Coordination Ability }\end{array}$ \\
\hline
\end{tabular}


TABLE 2. IPH MANAGEMENT PROCESS, CORE MEASURES AND STANDARDS BASED ON COMPETENCE HEALTH

\begin{tabular}{|c|c|c|c|}
\hline $\begin{array}{l}\text { Num- } \\
\text { ber }\end{array}$ & Core Measures & Standard Achievement & $\begin{array}{l}\text { Score } \\
\text { Assignment } \\
\text { Standard }\end{array}$ \\
\hline 1 & $\begin{array}{l}\text { Risk Cognitive Education and Competence Guidance } \\
48 \text { hours before Operation }\end{array}$ & $\begin{array}{l}\text { Familiar with the condition, know the operation method, } \\
\text { confirm the risk early warning }\end{array}$ & $\begin{array}{l}2 \text { points per } \\
\text { item }\end{array}$ \\
\hline 2 & $\begin{array}{l}\text { High-energy diet and physical exercise guidance to } \\
\text { ensure sleep quality }\end{array}$ & $\begin{array}{l}\text { Energy reserve }>30 \% \text {, physical stability, adequate sleep }>8 \\
\text { hours }\end{array}$ & $\begin{array}{l}2 \text { points per } \\
\text { item }\end{array}$ \\
\hline 3 & $\begin{array}{l}\text { Adaptive Education and Participatory Skills Guidance } \\
24 \text { hours before Operation }\end{array}$ & $\begin{array}{l}\text { Familiar with operating room environment, clear hypother- } \\
\text { mia response and understanding of treatment cooperation } \\
\text { requirements }\end{array}$ & $\begin{array}{l}2 \text { points per } \\
\text { item }\end{array}$ \\
\hline 4 & $\begin{array}{l}\text { Preoperative IPH Cognitive Education for Relatives } \\
\text { and Patient Care Guidance }\end{array}$ & $\begin{array}{l}\text { Actively provide health information, cooperate with patients } \\
\text { to control diet and complete physical exercise }\end{array}$ & $\begin{array}{l}2 \text { points per } \\
\text { item }\end{array}$ \\
\hline 5 & $\begin{array}{l}\text { Education and preoperative preparation of patients } \\
\text { within } 4 \text { hours before operation }\end{array}$ & $\begin{array}{l}\text { Psychological comfort and intervention of patients, preoper- } \\
\text { ative preparation and evaluation, nursing handover to meet } \\
\text { the standard }\end{array}$ & $\begin{array}{l}2 \text { points per } \\
\text { item }\end{array}$ \\
\hline 6 & $\begin{array}{l}\text { Patient guidance, anesthesia induction preheating and } \\
\text { environmental adaptation }\end{array}$ & $\begin{array}{l}\text { Timely communication and cooperation, accurate feedback, } \\
\text { preheating body temperature feeling up to standard }\end{array}$ & $\begin{array}{l}3 \text { points per } \\
\text { item }\end{array}$ \\
\hline 7 & $\begin{array}{l}\text { Position protection and accurate temperature moni- } \\
\text { toring and control equipment connection }\end{array}$ & $\begin{array}{l}\text { Room temperature standard, effective coverage, accurate } \\
\text { monitoring data, clear physical monitoring location }\end{array}$ & $\begin{array}{l}3 \text { points per } \\
\text { item }\end{array}$ \\
\hline 8 & $\begin{array}{l}\text { The alarm response and expectation are appropriate, } \\
\text { and the fluctuation of monitoring indicators is up to } \\
\text { the standard }\end{array}$ & $\begin{array}{l}\text { Active physical monitoring, adapting to alarm response, early } \\
\text { warning management up to standard, data fluctuation up to } \\
\text { standard }\end{array}$ & $\begin{array}{l}3 \text { points per } \\
\text { item }\end{array}$ \\
\hline 9 & $\begin{array}{l}\text { Awakening Preheating Management and Comfort } \\
\text { Feedback Reaching the Standard after Awakening }\end{array}$ & $\begin{array}{l}\text { Pre-heating management before operation, temperature of } \\
\text { awake precursor reaching standard and feedback reaching } \\
\text { standard after awakening }\end{array}$ & $\begin{array}{l}3 \text { points per } \\
\text { item }\end{array}$ \\
\hline 10 & $\begin{array}{l}\text { Transfer body temperature up to standard, key hando- } \\
\text { ver and monitoring clear }\end{array}$ & $\begin{array}{l}\text { Transfer temperature monitoring, ward handover, pa- } \\
\text { tients'feelings and relatives' evaluation to reach the standard }\end{array}$ & $\begin{array}{l}2 \text { points per } \\
\text { item }\end{array}$ \\
\hline 11 & $\begin{array}{l}\text { Postoperative } 24 \text {-hour temperature monitoring, doc- } \\
\text { tor-patient cooperation with rehabilitation exercise }\end{array}$ & $\begin{array}{l}\text { 24-hour body temperature monitoring after operation, } \\
\text { patient cooperation and rehabilitation, active prevention and } \\
\text { control of relatives }\end{array}$ & $\begin{array}{l}2 \text { points per } \\
\text { item }\end{array}$ \\
\hline 12 & $\begin{array}{l}\text { No complications occurred } 72 \text { hours after operation, } \\
\text { and the diet and physical fitness were up to standard. }\end{array}$ & $\begin{array}{l}\text { Overall health assessment, post-operative infection, car- } \\
\text { dio-cerebral accident, and overall data evaluation }\end{array}$ & $\begin{array}{l}3 \text { points per } \\
\text { item }\end{array}$ \\
\hline
\end{tabular}

The overall score was 93 points, and those with 2 points for each index were scored according to whether they met the criteria or not; those with 3 points were scored according to excellent, good and scorable;

Psychological intervention is based on psychological counseling and assisted with sedative drugs when necessary;

In addition to the dietary coordination of relatives, emphasis should be placed on the rehabilitation exercise of disabled limbs and the safety protection of patients during exercise.

\section{Prospective nursing observation method:}

We determined that patients with elective spinal surgery would be selected as the target. The selection criteria were age 18-65 years old, no gender limitations, junior high school and above education level, patients with normal intelligence and mental morality were assessed on admission. We agreed to the nursing research scheme and cooperated with each other. The expected operation time was 1 hour. The expected bleeding volume was less than $10 \mathrm{ml} / \mathrm{kg}$ over an hour. Exclusion criteria: Patients who did not agree to participate in this study, significant organ dysfunction before the surgery, precursor energy index less than grade 4, etc. According to the expectation, 120 patients were divided into two groups: group A (guided by health competence) and group B (guided by routine nursing). For group B, surgeons were required to submit the elective operation plan 48 hours in advance. The trained nurses in the ward and operating room were responsible for conducting health education and ability guidance for patients based strictly on the observation process and IPH measures and standards. The focus was to enhance the ability of patients to cope with the challenges of surgical treatment and self-management, including patients' relatives. In group B, perioperative nursing management and standardized operation were carried out according to the relevant guidelines and normative requirements ${ }^{2}$ and revised IPH prevention and control nursing standards by the expert group.

\section{Evaluation of patients' participation in safety management and satisfaction:}

All cooperation measures and supervision methods were applied by the patients. The evaluation of satisfaction with medical care was unified by the hospital health service department, and 30\% of discharged patients participated in face-to-face interviews that included a unified evaluation questionnaire. A total of 20 questions were scored as excellent; good, fair, poor, and inferior scored 5-1 points. 


\section{Observation Indicators and Records:}

Referring to a previous study ${ }^{2}$, the standards for temperature monitoring and management in the perioperative period were formulated, and the methods of temperature collection, intervention red flags, abnormal analysis, and treatment measures needed for comparative analysis at key time points were determined.

\section{Statistical analysis of data:}

All 120 patients completed data acquisition by SPSS21 Chinese software, and data was counted using the chi-square test (2) and measured by students t-test; $\mathrm{P}<0.05$ showed significant difference.

\section{RESULT}

The nursing observation of 120 patients was completed from March 2018 to October 2018. The average age of the 120 patients was $64.82+10.38$ years, and there were 51 males and 69 females, all of whom met the criteria for nursing observation. There were 49 cases of cervical and lumbar disc herniation, 37 cases of spinal stenosis, 23 cases of vertebral fracture, and 11 cases of intraspinal tumors. The operation time ranged from 1.2 hours to 3.9 hours, with an average of 2.16 + 0.42 hours. Preoperative coexistence included 24 cases of hypertension, 17 cases of diabetes, 9 cases of coronary heart disease, and 3 cases of chronic obstructive pulmonary disease. There was no serious cardiopulmonary, liver, kidney, brain, or other important organ dysfunctions before the operations. There was no significant difference between the two groups $(p$ $>0.05)$.

\section{Health Competence Survey:}

The statistical results of the doctor-patient health competence questionnaire are shown in Figure 1. The results show that the level of health competence in both groups is significantly higher than the basic value $(p<$ 0.01) through training and effective implementation. The results from the questionnaires in all the three different observation tine points were significantly better in group A than in group B. The comparison between the two groups found differences mainly in the health competence indicators in life, psychology, and society. The scores for indicators relating to roles, thoughts, morality, and spirit, in particular, were not satisfactory in group B, which shows that both doctors' and patients' attention to social and mental health is not high in the process of traditional medical services.

\section{Temperature management:}

The data show that the mean temperature at each time point in group A was significantly different from that in group $\mathrm{B}(\mathrm{P}<0.01)$. The patients' temperature stability was better, and the expected control index value more ideal.

\section{IPH-related events:}

A comparative analysis of IPH-related events between the two groups shows that the three indicators of myocardial ischemia, hypoxemia, and post-operative shivering in group B were significantly lower than those in group $A(p<0.01)$; there was a significant difference in postoperative infection $(p<0.05)$. The internal relationship analysis of the abnormal indicators shows that hypothermia affects microcirculation metabolism and impairs body immunity.

\section{FIGURE 1}

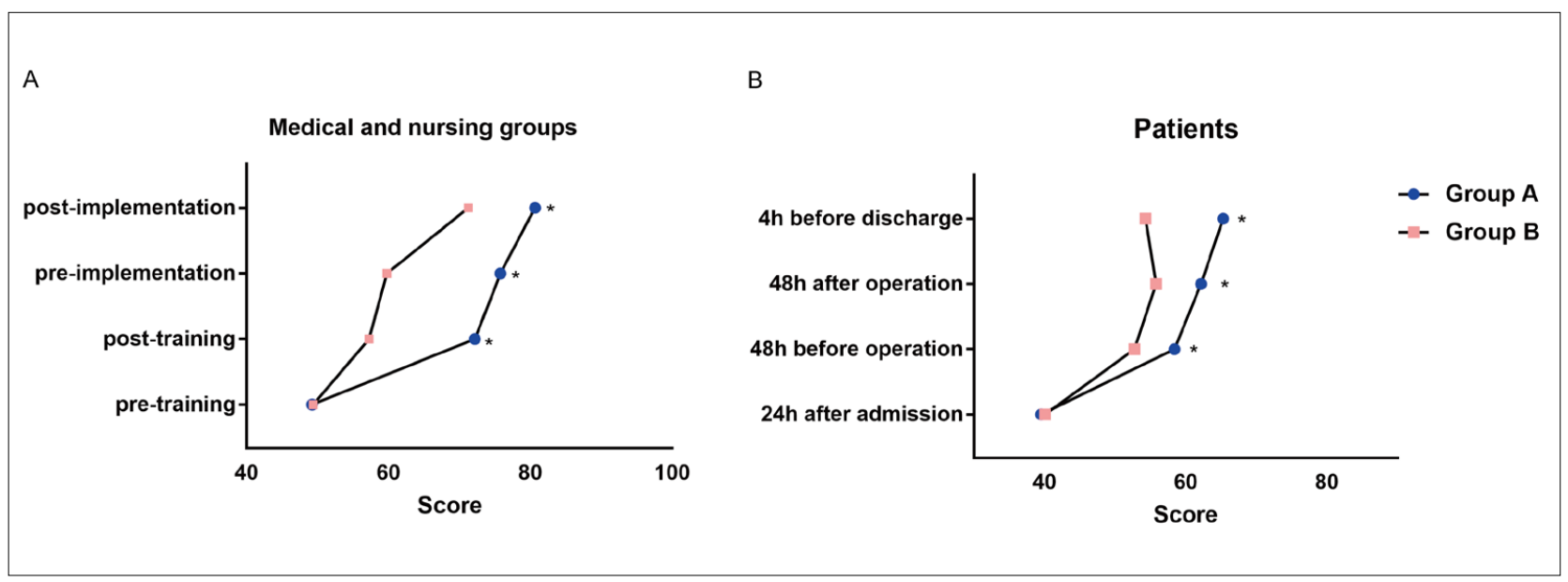




\section{Medical expenses and satisfaction:}

The hospitalization expenses, anesthesia expenses (excluding orthopedic surgery consumables) of the two groups were compared with the survey data from 72 hours after the operation or hospital discharge. The results showed that the total hospitalization expenses and ICU monitoring time of group A were significantly lower than those of group B $(p<0.001)$; the medical satisfaction and hospitalization days of group A were significantly different from those of group B $(p<0.01)$. The difference between anesthesia cost and medical satisfaction was significant $(<0.05)$, suggesting that IPH prevention and control based on health competence can significantly improve the quality of medical care, slow down IPH and its complications, reduce medical expenses, and improve inpatient health and medical satisfaction.

\section{DISCUSSION}

This article not only strengthens the management of the medical staff health competence health cultivation but minimizes the work flaws caused by occupational burnout. In group A, the head nurses cooperated with ward nurses, strengthening preoperative targeted active and passive physical exercise and increasing confidence in the surgical treatment for patients. Rehabilitation can also improve the tolerance of the body to changes in environmental temperature and promote the metabolism of myoblasts, improving patients' appetite and quality of dietary correction and compliance. Compared with group B, the standardized prevention and control management of IPH emphasizes holistic nursing management centered on patients' health. Medical burden is a concern of the government and family in the new era. The two groups of patients refused to use IPH prevention and control equipment when they signed the consent form based on preoperative health education, and group A was significantly higher than group B (31:18). Group $\mathrm{A}$, from the perspective of health competence, further optimized the use of relevant equipment indicators, and highlighted patient autonomy. Through targeted health guidance, patients' health competence level was improved, and the medical staff was actively assisted to optimize preoperative accuracy. Preparatory measures should be taken to improve the level of physical-psychological-mental health competence, reducing the incidence of IPH and the medical burden, and improving the satisfaction of inpatient health care.

\section{Acknowledgments}

In the process of demonstration and implementation of the nursing plan of this topic, Director Junxia Gu of Nursing Department, Directors Wenge Wang, Xinzhi Chen, Zhian Fu and Zhanfa Chen of Orthopedics Department, and Expert leaders such as Wu Ying and Head Nurse Chen Junli Strong for the support and training guidance.

\section{Disclosure}

The authors report no conflicts of interest in this work.

\section{Author's Contribution}

Conceptualization, Ji-Yue Shi; formal analysis, Tian-You Zhou; writing (original draft preparation), all authors; writing (review and editing), Ji-Yue Shi; supervision, Shu-Fang Du; funding acquisition, Ji-Yue Shi.

\section{RESUMO}

OBJETIVO: Explorar a viabilidade do cultivo da competência em saúde na prevenção e controle da hipotermia perioperativa inadvertida (IPH).

MÉTODOS: Pacientes com cirurgia espinhal marcada foram divididos em dois grupos, $A$ e $B$, pelo método de números aleatórios. O grupo B foi conduzido com base na gestão rotineira para prevenção de IPH; já no grupo $A$, foram implementadas medidas de treinamento em competência de saúde. As pontuações do questionário sobre competência em saúde, a temperatura aferida em diferentes momentos, complicações relacionadas à IPH e hospitalização dos dois grupos foram observadas e comparadas.

RESULTADOS: Os principais índices de avaliação, como a pontuação do questionário sobre competência em saúde, a variação de temperatura e as complicações relacionadas à IPH durante o período perioperatório foram significativamente melhores no grupo A do que no grupo $B(p<0,05)$. Os índices de anestesia, despesas hospitalares totais e satisfação com o serviço de saúde também foram significativamente melhores no grupo $A$ do que no $B$, o que demonstra as vantagens do cultivo da competência de saúde tanto em médicos como em pacientes. 
CONCLUSÃo: Por meio do cultivo de competências de saúde e de medidas viáveis de gestão da saúde, a equipe médica pode melhorar a qualidade da prevenção e gestão da IPH.

PALAVRAS-CHAVE: Período perioperatório. Hipotermia. Gestão em saúde.

\section{REFERENCES}

1. Torossian A, Van Gerven E, Geertsen K, Horn B, Van de Velde M, Raeder J. Active perioperative patient warming using a self-warming blanket (BARRIER EasyWarm) is superior to passive thermal insulation: a multinational, multicenter, randomized trial. J Clin Anesth. 2016;34:547-54.

2. Giuliano KK, Hendricks J. Inadvertent perioperative hypothermia: current nursing knowledge. AORN J. 2017;105(5):453-63.

3. Grønning K, Espnes GA, Nguyen C, Rodrigues AMF, Gregorio MJ, Sousa R, et al. Psychological distress in elderly people is associated with diet, wellbeing, health status, social support and physical functioning- a HUNT3 study. BMC Geriatr. 2018;18(1):205.

4. Jun JH, Chung MH, Kim EM, Jun IJ, Kim JH, Hyeon JS, et al. Effect of pre-warming on perioperative hypothermia during holmium laser enucleation of the prostate under spinal anesthesia: a prospective randomized controlled trial. BMC Anesthesiol. 2018;18(1):201.

5. Vaismoradi M, Jordan S, Kangasniemi M. Patient participation in patient safety and nursing input: a systematic review. I Clin Nurs. 2015;24(5-6):627-39.

6. Nielsen LD, Gildberg FA, Bech P, Lange Dalgaard I, Munksgaard G, Hounsgaard L. Forensic mental health clinician's experiences with and assessment of alliance regarding the patient's readiness to be released from mechanical restraint. Int | Ment Health Nurs. 2018;27(1):116-25.

7. Bu N, Zhao E, Gao Y, Zhao S, Bo W, Kong Z, et al. Association between perioperative hypothermia and surgical site infection: a meta-analysis. Medicine (Baltimore). 2019;98(6):e14392. 